\title{
Integrasi Karakter Bangsa Berbasis Pendekatan Saintifik pada Perencanaan Pembelajaran IPS SMPN di Kecamatan Sape, Bima
}

\author{
Ida Waluyati, Irfan, Nurnazmi \\ Program Studi Pendidikan Sosiologi, Jurusan Pendidikan IPS, STKIP BIMA, Jl. \\ Tendean Kel. Mande, Bima, Indonesia \\ Email Korespondensi: idawaluyati81@gmail.com
}

\begin{tabular}{|c|c|}
\hline$A r$ & bstract \\
\hline $\begin{array}{l}\text { Article History } \\
\text { Received: October } 2019 \\
\text { Revised: November } 2019 \\
\text { Published: December } 2019\end{array}$ & \multirow{2}{*}{$\begin{array}{l}\text { [Title: The Integrated of The Nations Characters Based on The Scientific Approach in } \\
\text { the Lesson Plan of Social Science at SMPN in Sape Regions, Bima]. The rage of } \\
\text { students delinquency that happens at Sape district, so the SMPN commit some efforts in } \\
\text { designing the lesson plan of social science based on the scientific approach.The research } \\
\text { aims to describe the integrity of the nations characters based on the scientific approach } \\
\text { in social science planning at SMPN in Sape Regions, Bima. The study uses the descriptive } \\
\text { qualitative approach. The subjects of the research are The headmaster, vice-headmaster } \\
\text { and } 6 \text { teachers of IPS that are chosen purposively sampling. The instruments that are } \\
\text { used: interview guide and documents. The technical analysis data that are used: } \\
\text { reduction, display and verification. The testing of the data validity using the triangle } \\
\text { source and tehcnics. The results results shows is sufficiently reprentative incarryng the } \\
\text { values of nations characters in each level of RPP that made are the characteristic } \\
\text { determinant of the achievement competency, the purpose of the study, learning methods, } \\
\text { and technical evaluation of leraning in which continued by the program over the study } \\
\text { result. Based on the results study, can be concluded thet the set of equipments which have } \\
\text { been arranged have shown the learning activity by using the scientific approach and by } \\
\text { integriting the characteristic values in every its component. }\end{array}$} \\
\hline $\begin{array}{l}\text { Nati } \\
\text { Scier } \\
\text { Less } \\
\text { Socit }\end{array}$ & \\
\hline Inforn & bstrak \\
\hline $\begin{array}{l}\text { Sejau } \\
\text { Diter } \\
\text { Dire } \\
\text { Dipu } \\
2019\end{array}$ & \multirow{2}{*}{$\begin{array}{l}\text { Kenakalan siswa semakin marak terjadi di Kecamatan Sape, Kabupaten Bima, maka } \\
\text { pihak SMPN melakukan upaya dalam merancang pembelajaran IPS yang berbasis } \\
\text { pendekatan saintifik. Penelitian ini bertujuan untuk mendeskripsikan integrasi karakter } \\
\text { bangsa berbasis pendekatan saintifik pada perencanaan pembelajaran IPS SMPN di } \\
\text { Kecamatan Sape, Bima. Penelitian ini menggunakan jenis deskriptif kualitatif. Subjek } \\
\text { penelitian adalah Kepala Sekolah dan Wakil Kepala Sekolah serta guru IPS sejumlah } 6 \\
\text { orang yang dipilih secara purposive sampling. Instrumen pengumpulan data berupa } \\
\text { pedoman wawancara dan dokumentasi. Teknik analisis data penelitian menggunakan } \\
\text { tahap reduksi, penyajian, serta verifikasi. Pengujian keabsahan data menggunakan } \\
\text { trianggulasi sumber dan teknik. Hasil penelitian menunjukkan bahwa integrasi karakter } \\
\text { bangsa berbasis pendekatan saintifik pada perencanaan pembelajaran IPS SMPN di } \\
\text { Kecamatan Sape, Bima cukup representatif dalam mencantumkan nilai-nilai karakter } \\
\text { bangsa pada setiap tahap RPP yang dibuat, antara lain penentuan indikator pencapaian } \\
\text { kompetensi (IPK), tujuan pembelajaran, metode pembelajaran, serta teknik evaluasi } \\
\text { pembelajaran yang di lanjutkan dengan program tindak lanjut hasil belajar. Berdasarkan } \\
\text { hasil penelitian dapat disimpulkan bahwa perangkat pembelajaran yang disusun telah } \\
\text { menunjukkan kegiatan pembelajaran dengan menggunakan pendekatan saintifik dengan } \\
\text { mengintegrasikan nilai-nilai karakter dalam setiap komponennya. }\end{array}$} \\
\hline $\begin{array}{l}\text { Kata } \\
\text { Kara } \\
\text { Peno } \\
\text { Pere } \\
\text { IPS }\end{array}$ & \\
\hline How to Cite this Article? & $\begin{array}{l}\text { Waluyati, I., Irfan., \& Nurnazmi. (2019). Integrasi Karakter Bangsa Berbasis } \\
\text { Pendekatan Saintifik pada Perencanaan Pembelajaran IPS SMPN di Kecamatan } \\
\text { Sape, Bima. Jurnal Penelitian dan Pengkajian Ilmu Pendidikan: e-Saintika, 3(2), 74-87. } \\
\text { DOI: https:// doi.org/10.36312/e-saintika.v3i2.140 }\end{array}$ \\
\hline
\end{tabular}




\section{PENDAHULUAN}

Indonesia memerlukan sumber daya manusia dalam jumlah dan mutu yang memadai sebagai pendukung utama dalam pembangunan. Untuk memenuhi sumber daya manusia tersebut, pendidikan memiliki peran yang sangat penting. Hal ini sesuai dengan UU No 20 Tahun 2003 tentang Sistem Pendidikan Nasional pada Pasal 3 menyebutkan bahwa pendidikan nasional berfungsi mengembangkan kemampuan dan membentuk karakter serta peradaban bangsa yang bermartabat dalam rangka mencerdaskan kehidupan bangsa.

Keberhasilan pendidikan nasional ditentukan oleh pendidikan karakter di sekolah. Pendidikan karakter sebagai suatu sistem penanaman nilai-nilai karakter kepada warga sekolah yang meliputi komponen pengetahuan, kesadaran atau kemauan, dan tindakan untuk melaksanakan nilai-nilai tersebut, baik terhadap Tuhan Yang Maha Esa (YME), diri sendiri, sesama, lingkungan, maupun kebangsaan sehingga menjadi manusia insan kamil. Pendidikan karakter dapat diintegrasikan dalam pembelajaran pada setiap mata pelajaran.

Dalam konteks kehidupan masyarakat, berbangsa, dan bernegara Indonesia, diyakini bahwa nilai dan karakter yang secara legal-formal dirumuskan sebagai fungsi dan tujuan pendidikan nasional, harus dimiliki peserta didik agar mampu menghadapi tantangan hidup pada saat ini dan di masa mendatang. Keprihatinan dan kerisauan berkaitan persoalan moral yang melanda para pelajar dewasa ini ditandai dengan merosotnya perilaku moral seperti etika berpakaian, etika pergaulan, serta perilaku peserta didik di ruang kelas, di lingkungan sekolah, maupun di luar sekolah. Persoalan moral tersebut tentu tidak bisa dilepaskan dari proses pendidikan dan pembelajaran yang cenderung kognitif-intelektualistik dan formalistik.

Karakter bangsa yang dimaknai sebagai pendidikan nilai, budi pekerti, moral, watak, atau akhlak yang tujuannya mengembangkan kemampuan peserta didik untuk memberikan keputusan baik-buruk, memelihara apa yang baik dan mewujudkan kebaikan dalam kehidupan sehari-hari dengan sepenuh hati yang meliputi indikator: religius, jujur, toleransi, disiplin, kerja keras, kreatif, mandiri, demokratis, rasa ingin tahu, semangat kebangsaan, cinta tanah air, menghargai persahabatan, bersahabat/komunikatif, cinta damai, gemar membaca, peduli lingkungan, peduli sosial, serta tanggung jawab. Hasil penelitian Nadlir (2013) dan Nugroho, dkk (2018) bahwa perencanaan pembelajaran berbasis karakter lebih difokuskan pada penekanan nilai-nilai karakter bangsa pada setiap komponenkomponen perangkat pembelajaran sebagai panduan dalam proses pembelajaran. Hal tersebut senada juga dengan hasil penelitian yang dilakukan oleh Cahyono (2015) bahwa pelaksanaan pendidikan karakter terintegrasi dalam setiap komponen pembelajaran.

Salah satu kebijakan dalam implementasi Kurikulum 2013 adalah perubahan paradigma pembelajaran dari berpusat kepada guru (teacher oriented) menjadi berpusat kepada siswa (student centered). Untuk mewujudkan hal tersebut, maka guru-guru diharapkan dapat menerapkan pendekatan saintifik (ilmiah) dalam kegiatan pembelajaran. Pendekatan ini difokuskan dalam memberikan pemahaman kepada peserta didik dalam mengenal dan memahami berbagai materi pembelajaran menggunakan langkah-langkah ilmiah yang meliputi: (1) Mengamati yakni peserta didik menggunakan panca inderanya untuk mengamati fenomena yang relevan 
dengan apa yang dipelajari, (2) Menanya yakni peserta didik merumuskan pertanyaan tentang apa yang tidak diketahui, (3) Mengumpulkan informasi yakni peserta didik mengumpulkan data melalui berbagai teknik, (4) Menalar/mengasosiasi, yakni peserta didik menggunakan data atau informasi yang sudah dikumpulkan untuk menjawab pertanyaan-pertanyaan yang dirumuskan, (5) Mengomunikasikan yakni peserta didik menyampaikan jawaban terhadap pertanyaan-pertanyaan ke kelas secara lisan, tertulis atau media lain. Hal tersebut didukung oleh hasil penelitian yang dilakukan oleh Puspitarini (2015) dan Wardana (2017) serta Sujarwo (2017) bahwa penggunaan pendekatan saintifik sangat berpengaruh dalam penanaman nilai-nilai karakter bangsa dalam setiap langkahlangkah ilmiahnya yakni berpikir kritis, tanggungjawab, kerja keras, serta komunikasi/kolaboratif.

Pendekatan saintifik ini diterapkan pada pembelajaran IPS yang diawali dengan perencanaan pembelajaran dengan melakukan pengembangan perangkat pembelajaran yang bermuatan karakter berbasis pendekatan saintifik berupa Silabus, RPP, bahan ajar. Hal tersebut senada dengan hasil penelitian yang dilakukan oleh Wahyuningsih dan Mustadi (2015) serta Kadek dan Wirawa (2014), bahwa pada tahap perencanaan pembelajaran, pengembangan RPP tematik-integratif dapat meningkatkan nilai karakter pada peserta didik.

Berdasarkan data statistik dari Unit Pelaksana Tugas Pendidikan, Kebudayaan, Pemuda dan Olahraga Kecamatan Sape, Kabupaten Bima bahwa terdapat enam SMP Negeri yang telah melaksanakan Kurikulum 2013 sejak tahun pelajaran 2017/2018, yaitu SMPN 2 Sape, SMPN 3 Sape, SMPN 4 Sape, SMPN 6 Sape, SMPN 7 Sape, serta SMPN 8 Sape. Sedangkan SMPN 1 Sape dan SMPN 5 Sape telah lebih awal merintis dalam pelaksanakan Kurikulum 2013, yakni sejak tahun pelajaran 2016/2017. Penelitian ini hanya difokuskan pada dua sekolah, yakni SMPN 1 Sape dan SMPN 5 Sape dengan pertimbangan bahwa kedua sekolah ini dinilai sudah dua tahun berjalan melaksanakan Kurikulum 2013 yaitu kelas VII dan VIII dibandingkan dengan keenam sekolah lainnya yang baru satu tahun dalam pelaksanaan Kurikulum 2013.

Hasil wawancara dengan Kepala Sekolah dan guru IPS pada kedua SMPN tersebut bahwa sejak tahun 2017 terdapat berbagai permasalahan yang berkaitan dengan sikap dan perilaku peserta didik yang tidak mencerminkan nilai-nilai karakter dalam pembelajaran IPS. Hal tersebut dibuktikan dengan adanya berbagai pengaduan yang ditujukan kepada pihak sekolah, antara lain, siswa sering bolos sebanyak $5 \%$, siswa mengganggu teman pada saat pembelajaran IPS, kurangnya motivasi belajar, siswa membawa senjata tajam, dan bahkan saling berkelahi sampai berujung pada pengaduan ke pihak Kepolisian setempat.

Salah satu gagasan utama untuk mengatasi persoalan moral tersebut yakni melalui pendekatan saintifik dalam tahapan perencanaan pembelajaran. Pendekatan Saintifik pada pembelajaran IPS di tingkat SMP diperlukan sebagai pendekatan dalam mengintegrasikan nilai-nilai karakter bangsa pada peserta didik di tengah degradasi moral yang terjadi di abad ke-21 sebagaimana amanat kurikulum 2013. Pembelajaran IPS menurut Ellis (1997) sebagai mata pelajaran yang diberikan pada kurikulum Sekolah Dasar dan Menengah memiliki peran vital dalam pembentukan karakter bangsa sebab melalui pembelajaran IPS, peserta didik diajarkan untuk menjadi warga negara Indonesia yang baik dan penuh kedamaian. 
Dalam konteks pembelajaran menurut Gay et al (2012) bahwa pendekatan saintifik sangat penting digunakan untuk mengembangkan cara-cara berpikir dan bekerja secara ilmiah. Konsep dasar mengenai proses pembelajaran menurut pendekatan saintifik yaitu bahwa peserta didik dipandang sebagai subjek yang memiliki kemampuan untuk secara aktif mencari, mengolah, mengkonstruksi, dan menggunakan pengetahuan yang terdiri dari lima langkah kegiatan belajar, yakni mengamati, menanya, mengumpulkan informasi, menalar, mengomunikasikan sebagaimana tertera pada Gambar 1 berikut.

\section{Mengamati 4 Menanya Menalar 4 Mencoba 4 Mengomunikasikan}

Gambar 1. Langah-Langkah Pembelajaran Saintifik

Muatan karakter secara psikologis menurut Lickona (1991) mencakup dimensi moral reasoning, moral feeling, dan moral behavior yang ditanamkan kepada warga sekolah agar terinternalisasi melalui sikap dan perilaku positif yang dilakukan melalui pembiasaan dan keteladanan. Karakter bangsa sebagai kualitas perilaku kolektif kebangsaan yang khas-baik yang tercermin dalam kesadaran, pemahaman, rasa, karsa, dan perilaku berbangsa dan bernegara sebagai hasil olah pikir, olah hati, olah rasa dan karsa, serta olah raga seseorang atau sekelompok orang sebagaimana tertera pada Gambar 2 berikut.

\section{PENDIDIKAN KARAKTER}
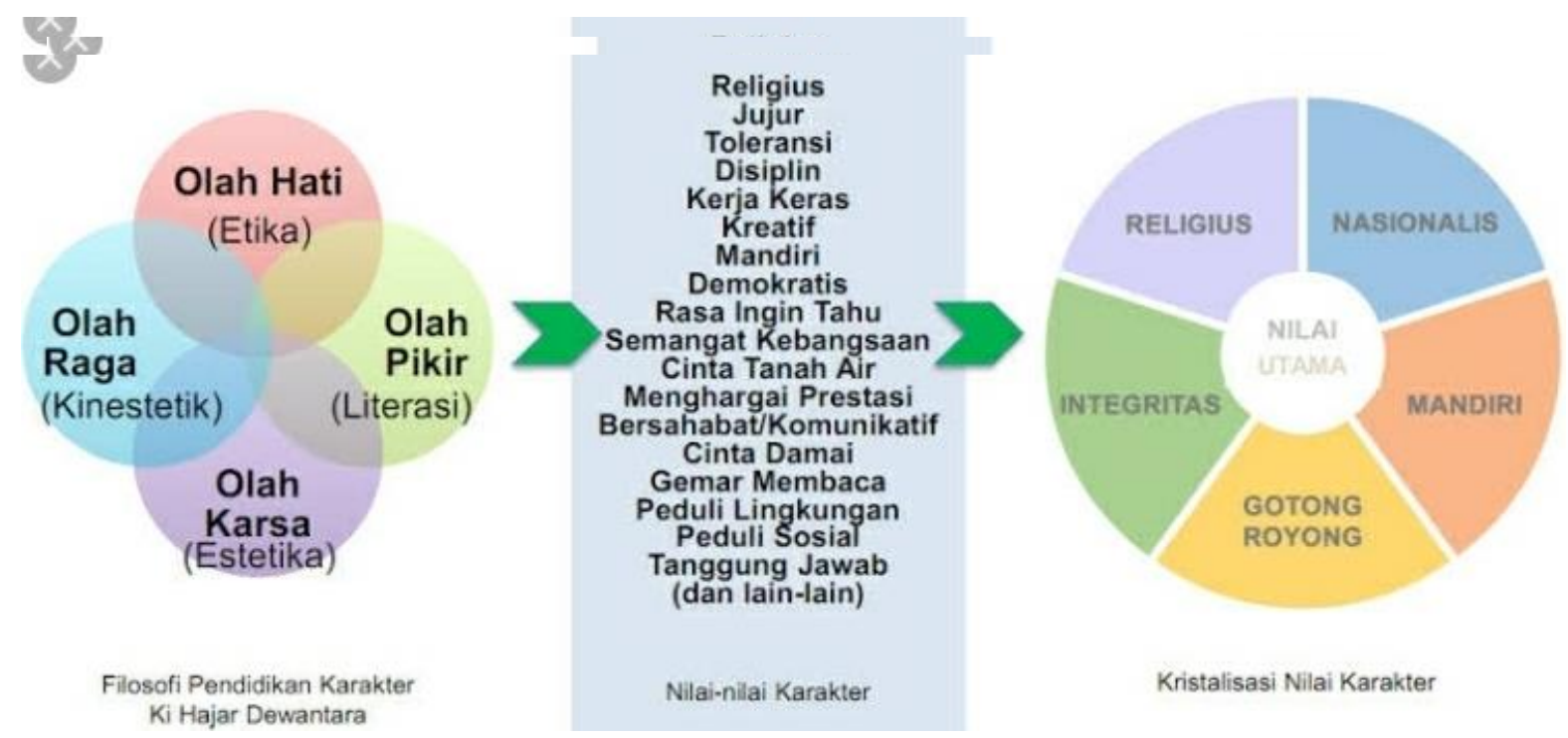

Gambar 2. Nilai-Nilai Pendidikan Karakter Bangsa

Integrasi Nilai Karakter Bangsa Dalam Pembelajaran IPS dalam Panduan Pembelajaran Untuk Sekolah Menengah Pertama, Direktorat Jenderal Pendidikan Dasar dan Menengah Kemendikbud (2016) dinyatakan bahwa prinsip pengembangan nilai-nilai karakter bangsa dalam pembelajaran IPS adalah dengan mengupayakan peserta didik mengenal dan menerima nilai-nilai karakter tersebut sebagai milik 
mereka dan bertanggung jawab atas keputusan yang diambilnya melalui tahapan mengenal pilihan, menilai pilihan, menentukan pilihan, menentukan pendirian, selanjutnya menjadikan suatu nilai sesuai dengan keyakinan diri. Dengan prinsip ini, peserta didik belajar melalui proses berpikir, bersikap, dan berbuat sebagaimana tahapan pendekatan saintifik. Integrasi karakter bangsa berbasis pendekatan saintifik dalam pembelajaran IPS pada tahap perencanaan pembelajaran yakni melalui pengembangan perangkat pembelajaran berupa silabus, RPP, serta bahan ajar yang dilakukan oleh guru. Hal tersebut didukung oleh hasil penelitian yang dilakukan oleh Wandan (2017) bahwa implementasi pendidikan karakter pada mata pelajaran IPS perlu didukung melalui pengembangan rancangan RPP yang berkarakter.

Pembelajaran yang efektif harus melalui tahap perencanaan yang baik. Berdasarkan Permendikbud Nomor 22 Tahun 2016, perencanaan pembelajaran harus mengacu pada Standar Isi dan meliputi penyusunan perangkat pembelajaran yang meliputi Silabus, Rencana Pelaksanaan Pembelajaran (RPP), bahan ajar, penyiapan media dan sumber serta perangkat penilaian pembelajaran. penyusunan Silabus dan RPP disesuaikan dengan pendekatan pembelajaran yang digunakan, dan komponen beserta format Silabus dan RPP disesuaikan dengan perundangan yang berlaku.

Perencanaan pembelajaran yang baik harus dilaksanakan dengan baik pula. Kurikulum 2013 mengharuskan pelaksanaan pembelajaran dibagi menjadi tiga tahap besar, yaitu pembukaan, kegiatan inti, dan penutup. Silabus dan RPP harus dengan sengaja dirancang umtuk pembelajaran yang tidak hanya menjadikan siswa memperoleh pengetahuan dan keterampilan, tetapi juga menumbuhkan budi pekerti. Selanjutnya kegiatan-kegiatan pembelajaran yang menantang dan menyenangkan yang telah dirancang dalam RPP dilaksanakan dengan sungguh-sungguh. Hal tersebut senada dengan hasil penelitian yang dilakukan oleh Afandi (2011) bahwa dalam pembelajaran IPS sebagai mata pelajaran yang mengkaji kehidupan sosial perlu memasukkan nilai-nilai pendidikan karakter dengan mengintegrasikannya dalam materi pembelajaran. Akhirnya perkembangan budi pekerti siswa diikuti dan difasilitasi terus-menerus hingga secara konsisten menampilkan karakter yang dilandasi oleh nilai-nilai moral yang baik. Berdasarkan hal tersebut, maka penelitian ini bertujuan untuk mengkaji dan mendeskripsikan secara mendalam terkait integrasi nilai-nilai karakter bangsa berbasis pendekatan saintifik pada perencanaan pembelajaran IPS SMPN di Kecamatan Sape, Kabupaten Bima.

\section{METODE PENELITIAN Jenis Penelitian}

Penelitian ini merupakan penelitian deskriptif kualitatif naturalistik untuk menggambarkan integrasi karakter bangsa berbasis pendekatan saintifik pada tahap perencanaan pembelajaran IPS SMPN di Kecamatan Sape, Kabupaten Bima.

\section{Subjek Penelitian}

Subyek penelitian ini adalah terdiri dari informan utama yang berasal dari guru IPS kelas VII dan kelas VIII yang berjumlah 6 orang dan pada SMPN 1 Sape dan SMPN 5 Sape dengan kriteria pemilihan subjek melalui teknik purposive sampling yakni pengambilan sumber data dengan pertimbangan tertentu dengan mengambil 3 orang responden dari setiap sekolah. Selanjutnya data penelitian dikembangkan menggunakan teknik snowball sampling yang berasal dari subjek (informan tambahan) 
yang terdiri dari Kepala Sekolah dan Wakil Kepala Sekolah untuk memperoleh data tambahan terkait perilaku penyimpangan siswa dan integrasi karakter bangsa pada perencanaan pembelajaran IPS di sekolah.

\section{Prosedur Penelitian}

Penelitian ini menggunakan prosedur melalui kegiatan pengumpulan data, menganalisis data, menginterpretasi data, serta diakhiri dengan sebuah kesimpulan yang mengacu pada penganalisisan data tersebut. Adapun prosedur penelitian dapat disajikan pada Gambar 3 berikut.

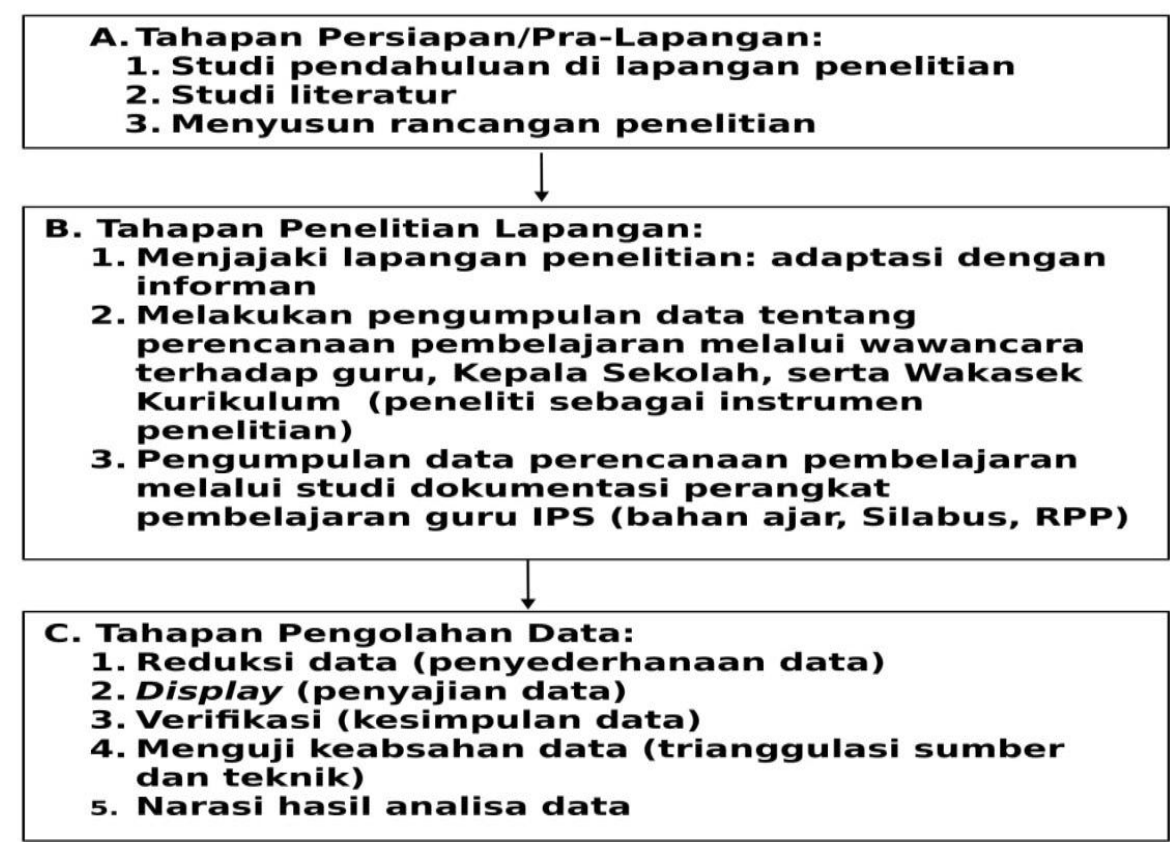

Gambar 3. Prosedur Penelitian

\section{Teknik Pengumpulan Data}

Teknik pengumpulan data yang digunakan dalam penelitian ini adalah berupa (1) Wawancara terhadap guru bidang studi IPS kelas VII dan VIII, Kepala Sekolah dan Wakil Kepala Sekolah, (2) Dokumentasi berupa perangkat pembelajaran guru IPS berupa, bahan ajar, Silabus dan RPP.

\section{Instrumen Penelitian}

Instrumen yang digunakan dalam penelitian ini adalah pedoman wawancara dan dokumentasi untuk menelaah dokumen bahan ajar, RPP dan Silabus yang bermuatan nilai-nilai karakter berbasis pendekatan saintifik.

\section{Pemeriksaan Keabsahan Data}

Teknik pemeriksaan keabsahan data dalam penelitian ini menggunakan teknik trianggulasi data untuk mengecek keabsahan data tertentu dengan membandingkan data yang diperoleh dari sumber dan teknik lain. Trianggulasi yang digunakan dalam penelitian ini adalah trianggulasi sumber yang dilakukan dengan membandingkan data yang diperoleh dari beberapa informan utama dengan informan tambahan yakni guru IPS kelas VII dan VIII, serta Kepala Sekolah dan Wakil Kepala Sekolah. Disamping itu, dalam penelitian ini digunakan juga trianggulasi teknik yang dilakukan dengan mengecek data kepada sumber yang sama dan dengan teknik yang berbeda dengan membandingkan data hasil wawancara dengan dokumentasi. 


\section{Teknik Analisis Data}

Teknik analisis data dalam penelitian ini menggunakan langkah-langkah teknik analisis data kualitatif yang dikemukakan oleh Miles dan Huberman (1992). Langkah-langkah tersebut meliputi reduksi (penyerderhanaan data), tahap display (penyajian data), serta verifikasi (kesimpulan data).

\section{HASIL DAN PEMBAHASAN Hasil Penelitian}

Integrasi karakter bangsa berbasis pendekatan saintifik pada perencanaan pembelajaran IPS di SMP Negeri Kecamatan Sape, Bima dapat dianalisis dalam tiga tahap pendekatan deskriptif kualitatif meliputi:

\section{A. Tahap Reduksi Data}

Berdasarkan hasil wawancara dengan Kepala Sekolah dan Wakasek Kurikulum SMP Negeri 5 Sape bahwa sebelum melaksanakan pembelajaran IPS, guru membuat perencanaan pembelajaran dengan menyusun Silabus, RPP dan bahan ajar. RPP yang disusun oleh guru memuat nilai-nilai karakter yang akan ditanamkan kepada peserta didik melalui proses pembelajaran. RPP yang disusun oleh guru IPS mencakup komponen Kompetensi Inti, Kompetensi Dasar, Indikator, tujuan pembelajaran, metode, langkah-langkah pembelajaran serta penilaian hasil belajar . Lebih lanjut menurut Wakasek Kurikulum SMP Negeri 1 Sape dan Wakasek SMP Negeri 5 Sape bahwa rancangan integrasi nilai-nilai karakter dalam perencanaan pembelajaran yang dilakukan oleh guru IPS di sekolah, terlebih dahulu mengkaji rumusan kompetensi yang akan dikuasai peserta didik dengan mengidentifikasi nilainilai karakter yang akan ditanamkan kepada peserta didik.

Terkait bentuk integrasi karakter bangsa berdasarkan pendekatan saintifik pada aspek perencanaan pembelajaran IPS, hasil wawancara dengan Kepala Sekolah dan Wakasek SMP Negeri 1 dan SMP Negeri 5 Sape dapat terlihat pada perangkat pembelajaran berupa RPP yang cukup representatif dalam mencantumkan nilai-nilai karakter bangsa pada setiap tahap RPP yang dibuat, antara lain penentuan indikator pencapaian kompetensi (IPK), tujuan pembelajaran, metode/model pembelajaran, serta teknik evaluasi pembelajaran yang di lanjutkan dengan program tindak lanjut hasil belajar. Disamping itu, untuk mendukung penanaman nilai-nilai karakter tersebut pada diri siswa dalam pembelajaran tersebut, pihak sekolah menyediakan bantuan buku teks pelajaran buat guru dan siswa. Berbagai media pembelajaran serta alat dan bahan yang mendukung penyampaian materi pembelajaran terutama dalam penggunaan pendekatan saintifik berupa peta, laptop, serta LCD.

Hasil wawancara dengan 6 (enam) orang Guru IPS kelas VII dan kelas VIII SMP 1 Negeri Sape dan SMP Negeri 5 Sape yang menjadi responden dalam penelitian ini terkait integrasi nilai-nilai karakter bangsa berbasis pendekatan saintifik dalam perencanaan pembelajaran IPS dapat dilakukan dengan mengembangkan perangkat pembelajaran berupa perangkat Silabus, RPP, maupun bahan ajar. Perencanaan pembelajaran dikembangkan berdasarkan silabus dan dikembangkan secara berkesinambungan. Perencanaan pembelajaran IPS memuat tahap-tahap kegiatan pembelajaran untuk setiap pertemuan. Tahapan kegiatan pembelajaran tersebut dikembangkan dengan tujuan memberi kesempatan kepada peserta didik untuk belajar menguasai sejumlah kompetensi dengan tetap mengedepankan aktualisasi nilai-nilai karakter bangsa baik didalam maupun luar kelas. Langkah-langkah 
menyusun rancangan pembelajaran meliputi, menulis identitas mata pelajaran, menulis $\mathrm{KI}, \mathrm{KD}$, mengembangkan langkah-langkah pembelajaran, metode, media pembelajaran, serta evaluasi pembelajaran dan tindak lanjut.

Berdasarkan hasil analisis dokumen RPP dari enam guru IPS, format yang digunakan sesuai dengan Permendikbud No 103 Tahun 2014. Setiap RPP yang disusun oleh guru IPS tercantum proses pembelajaran yang dilakukan dengan menerapkan pendekatan saintifik yang meliputi kegiatan mengamati, menanya, mengumpulkan informasi, menalar, serta mengomunikasikan melalui penggunaan berbagai metode pembelajaran yang bervariasi mengaktifkan siswa antara lain, problem solving, cooperatif learning, project based learning, serta inkuiri. Pada pemilihan metode pembelajaran inilah, penekanan perilaku kebiasaan-kebiasaan yang baik (karakter bangsa) pada diri siswa melalui tiga tahap kegiatan pembelajaran yaitu tahap pendahuluan, inti, dan penutup. Disinilah penanaman nilai karakter bangsa dilakukan oleh guru IPS antara lain, kerjasama, kolaboratif, berpikir kritis, keaktifan, tanggungjawab, berani mencoba, serta displin.

Untuk mendukung data hasil wawancara, dilakukan juga telaah dokumen bahan ajar, Silabus dan RPP mata pelajaran IPS guru di SMPN Kecamatan Sape, Bima. Adapun integrasi nilai-nilai karakter bangsa didapatkan dengan cara menganalisis nilai-nilai karakter yang terkandung dari Kompetensi Inti (KI) maupun Kompetensi Dasar (KD). Nilai karakter tersebut nantinya dimasukkan ke dalam RPP antara lain religius, disiplin, tanggungjawab, peduli, toleransi, kerjasama, kerja keras. Untuk lebih jelasnya, hasil telaah dokumen RPP dan Silabus tersebut dapat dijelaskan pada tahap display data berikut.

B. Tahap Penyajian Data (Display Data)

Adapun hasil telaah dokumen Silabus dan RPP IPS SMPN di Kecamatan Sape, Bima dapat dijelaskan pada Tabel 1 berikut:

Tabel 1. Hasil Telaah Dokumen Silabus dan RPP IPS SMPN di Kecamatan Sape, Bima

\begin{tabular}{|c|c|c|c|c|}
\hline No & & Komponen & Indikator & Keterangan \\
\hline 1 & $\mathrm{~A}$ & $\begin{array}{l}\text { Identitas Mata } \\
\text { Pelajaran/ } \\
\text { Tema, } \\
\text { Kompetensi Inti, } \\
\text { Kompetensi } \\
\text { Dasar, Indikator } \\
\text { Pencapaian } \\
\text { Kompetensi }\end{array}$ & $\begin{array}{l}\text { Menuliskan KI dan IPK } \\
\text { dengan lengkap dan benar } \\
\text { dan memuat nilai-nilai } \\
\text { karakter bangsa (KI-1 dan } \\
\text { KI-2) yang mencakup } \\
\text { kompetensi pengetahuan, } \\
\text { keterampilan, dan sikap } \\
\text { sesuai dengan KD. }\end{array}$ & $\begin{array}{l}\text { 1. } \text { guru mencantumkan } \\
\text { lengkap indikator tersebut } \\
\text { pada komponen RPP } \\
\text { 2. guru menuliskan KI-1 } \\
\text { (Kompetensi spiritual) dan } \\
\text { KI-2 (kompetensi sosial) } \\
\text { sesuai jenjang kelas pada } \\
\text { Mapel IPS sesuai cakupan, } \\
\text { kedalaman KD, alokasi } \\
\text { waktu serta karakteristik } \\
\text { siswa yang diajarkan }\end{array}$ \\
\hline 2 & B & $\begin{array}{l}\text { Tujuan } \\
\text { Pembelajaran, } \\
\text { Materi } \\
\text { Pembelajaran }\end{array}$ & $\begin{array}{l}\text { 1. Tujuan Pembelajaran } \\
\text { memuat nilai-nilai } \\
\text { karakter bangsa sesuai } \\
\text { muatan KI-1 \& KI-2 } \\
\text { (spiritual dan sosial) } \\
\text { 2. } \text { Tujuan pembelajaran } \\
\text { mengandung unsur: } \\
\text { audience (A), behavior } \\
\text { (B), condition (C), dan } \\
\text { degree (D). }\end{array}$ & $\begin{array}{l}\text { 1. guru merumuskan tujuan } \\
\text { pembelajaran sesuai dengan } \\
\text { IPK, bersifat lebih } \\
\text { operasional, serta } \\
\text { memadukan dengan nilai- } \\
\text { nilai karakter bangsa yang } \\
\text { tercakup dalam KI-1 dan KI- } \\
2 \\
\text { 2. guru memilih materi sesuai } \\
\text { IPK dan tujuan } \\
\text { pembelajaran, alokasi waktu, }\end{array}$ \\
\hline
\end{tabular}




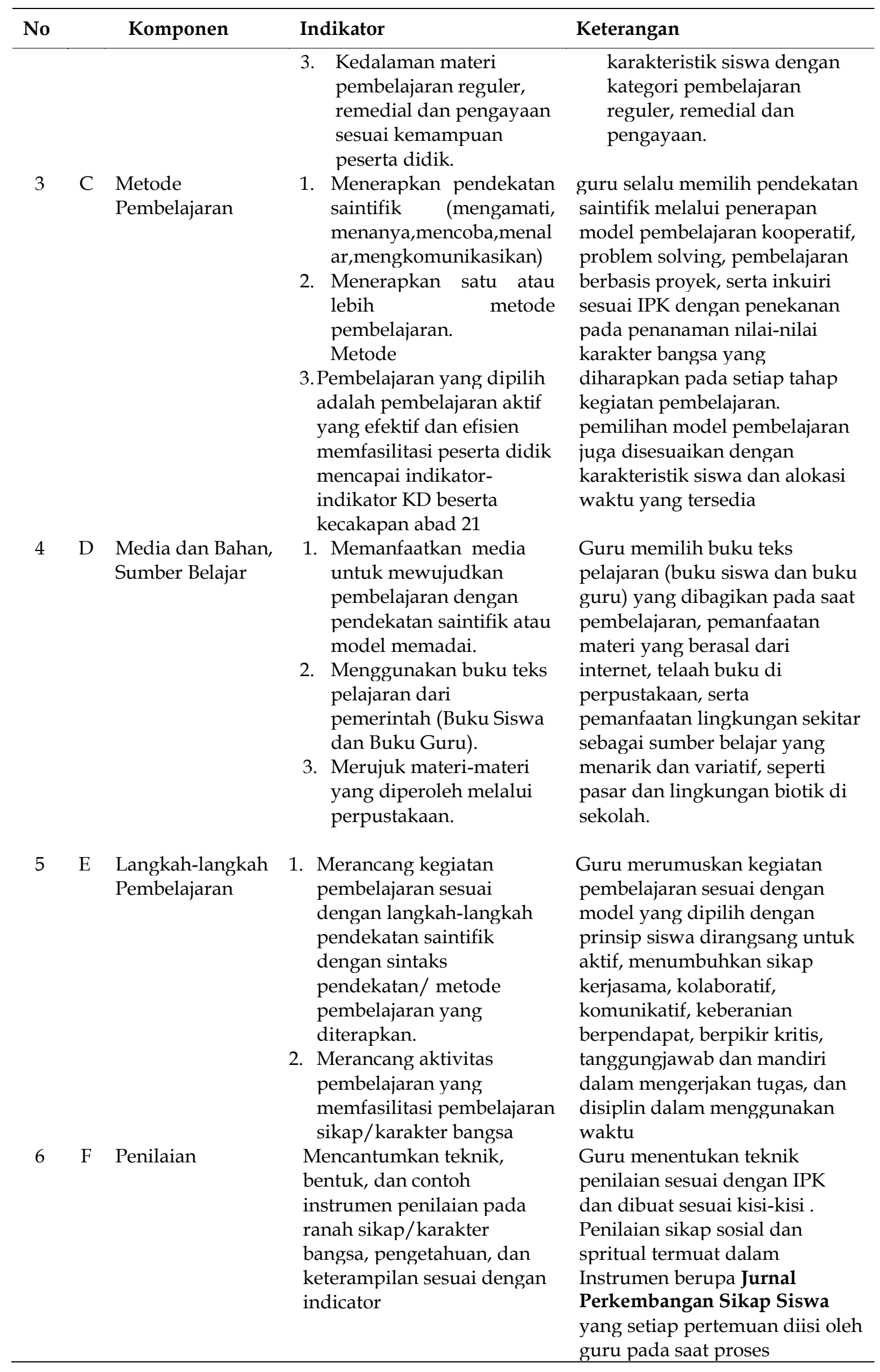




\begin{tabular}{|c|c|c|c|c|}
\hline No & & Komponen & Indikator & Keterangan \\
\hline 7 & $\mathrm{~J}$ & $\begin{array}{l}\text { Integrasi Gerakan } \\
\text { Literasi Sekolah } \\
\text { (GLS) }\end{array}$ & $\begin{array}{l}\text { A. Strategi Literasi dalam } \\
\text { Pembelajaran } \\
\text { 1. Sebelum "membaca" } \\
\text { a. mengidentifikasi } \\
\text { tujuan membaca } \\
\text { b. membuat prediksi } \\
\text { 2. Ketika "membaca" } \\
\text { a. mengidentifikasi } \\
\text { informasi yang relevan } \\
\text { b. mengidentifikasi } \\
\text { kosakata baru, kata } \\
\text { kunci, dan/atau kata } \\
\text { sulit dalam teks } \\
\text { 3. Setelah "membaca" } \\
\text { a. membuat "ringkasan } \\
\text { b. mengevaluasi teks }\end{array}$ & $\begin{array}{l}\text { pembelajaran. sedangkan } \\
\text { penilaian keterampilan termuat } \\
\text { dalam instrumen Penilaian } \\
\text { keterampilan pada saat kegiatan } \\
\text { pembelajaran berlangsung, } \\
\text { misalnya pada saat diskusi } \\
\text { kelompok, kesimpulan } \\
\text { pembelajaran, tanya jawab, } \\
\text { presentasi kelompok } \\
\text { Guru menanamkan kegiatan } \\
\text { literasi dengan memanfaatkan } \\
\text { buku teks pelajaran yang } \\
\text { disediakan sekolah dengan } \\
\text { membagikan pada siswa setiap } \\
\text { kegiatan pembelajaran. }\end{array}$ \\
\hline
\end{tabular}

Bahan ajar sebagai komponen pembelajaran yang paling berpengaruh terhadap proses pembelajaran, guru mata pelajaran IPS di Kecamatan Sape, Bima umumnya berbasis aktivitas/kegiatan belajar, baik secara eksplisit atau implisit terbentuk atas enam komponen yaitu:

Tabel 2. Integrasi Karakter Bangsa pada Komponen Bahan Ajar IPS

\begin{tabular}{llll}
\hline No & Komponen Bahan ajar & Nilai Karakter yang ditumbuhkan \\
\hline 1. & Tujuan: beroritentasi pada & sikap, & $\begin{array}{l}\text { Kejujuran, rasa percaya diri, kerja } \\
\text { pengetahuan, keterampilan }\end{array}$
\end{tabular}

2. Input: rujukan/bahan sebagai pangkal Motivasi diri siswa, disiplin tolak dilaksanakannya aktivitas belajar oleh peserta didik (video, grafik, gambar, model)

3. Aktivitas: upaya yang dilakukan oleh Kerja keras, tanggungjawab, peserta didik dengan input belajar disiplin, saling menghargai, untuk mencapai tujuan belajar (debat, komunikasi, kerjasama, berpikir diskusi, observasi, presentasi, proyek) kritis, toleransi, kreatif

4. Pengaturan (setting): berkaitan dengan Siswa terbiasa kerja dengan cepat, kapan dan dimana kegiatan kemampuan kerjasama, saling pembelajaran dilaksanakan menghargai, disiplin

5. Peran guru: fasilitator, motivator, Motivasi, kerjasama, saling partisipan, pemberi umpan balik menghargai 


\begin{tabular}{lll}
\hline No & Komponen Bahan ajar & Nilai Karakter yang ditumbuhkan \\
\hline & $\begin{array}{l}\text { dinyatakan secara eksplisit dalam } \\
\text { bahan ajar }\end{array}$ & \\
6. Peran peserta didik dinyatakan secara & Kerjasama, Tanggungjawab, \\
implisit dalam bahan ajar melalui disiplin, komunikasi, Kerja keras \\
penyaji hasil diskusi, pelaksana proyek, \\
partisipan diskusi
\end{tabular}

Bahan ajar IPS di SMPN Kecamatan Sape telah disiapkan oleh pemerintah melalui buku teks pelajaran untuk pelaksanaan Kurikulum 2013. Namun buku tersebut tidak selalu memenuhi sejumlah kriteria kelayakan dalam mengintegrasikan penumbuhan karakter secara memadai didalamnya. Oleh karena itu, sejalan dengan apa yang telah dirancang pada Silabus dan RPP yang berwawasan penumbuhan budi perkerti, bahan ajar diadaptasi pada bagaian-bagian tertentu oleh guru IPS.

\section{Tahap Verifikasi Data (Kesimpulan Data)}

Berdasarkan hasil telaah perangkat pembelajaran IPS pada SMPN di Kecamatan Sape, Bima tersebut bahwa untuk menumbuhkan nilai karakter bangsa pada aspek perencanaan pembelajaran, guru mencantumkan Kompetensi Inti, Kompetensi Dasar, Indikator Pencapaian Kompetensi, kegiatan pembelajaran, serta teknik penilaian yang efektif untuk mengembangkan nilai-nilai karakter siswa. Hal tersebut senada dengan hasil penelitian yang dilakukan oleh Zuchdi dan Kun (2010) serta Sudrajat dan Wibowo (2013) bahwa penanaman nilai-nilai karakter dilakukan secara terintegrasi dalam pembelajaran bidang studi mulai dari pengembangan perangkat pembelajaran sampai pada evaluasi hasil belajar.

\section{Pembahasan}

Setiap pembelajaran menghendaki perencanaan yang baik yang dituangkan dalam bentuk bahan ajar, Silabus dan RPP. Berdasarkan data hasil penelitian bahwa integrasi karakter bangsa berbasis pendekatan saintifik pada aspek perencanaan pembelajaran IPS di SMP Negeri Kecamatan Sape, Bima termuat dalam perangkat pembelajaran yang dibuat dalam satu tahun meliputi, Silabus dan RPP. Berdasarkan hasil penelitian bahwa pengembangan perencanaan pembelajaran pada SMP Negeri di Kecamatan Sape antara lain dengan merevisi bahan ajar, Silabus dan RPP yang memuat sekurang-kurangnya tujuan pembelajaran, materi pembelajaran, metode pembelajaran, sumber belajar, langkah-langkah pembelajaran serta penilaian hasil belajar yang bermuatan nilai-nilai karakter didalamnya. RPP yang dijabarkan dari silabus untuk mengarahkan kegiatan belajar peserta didik dalam upaya mencapai Kompetensi Dasar. Hal ini sejalan dengan hasil kajian Mardzuki (2012) terkait pengintegrasian pendidikan karakter dalam perencanaan pembelajaran di Sekolah dengan melakukan analisis SK/KD, pengembangan Silabus, RPP, serta bahan ajar yang berkarakter.

Rencana Pelaksanaan Pembelajaran menurut Kemendikbud (2016) digunakan sebagai rencana yang menggambarkan prosedur dan pengorganisasian pembelajaran untuk mencapai satu kompetensi dasar yang ditetapkan dalam Standar Isi dan telah dijabarkan dalam Silabus. Lingkup RPP paling luas mencakup 1 (satu) kompetensi 
dasar yang terdiri atas 1 (satu) atau beberapa indikator untuk 1 (satu) kali pertemuan atau lebih. RPP dijabarkan dari silabus untuk mengarahkan kegiatan belajar peserta didik dalam upaya mencapai KD.

Tujuan IPS menurut Massialas dan Allen (1996) dalam membekali peserta didik agar memiliki keterampilan sosial sehingga dapat beradaptasi ditengah keberagaman budaya dan kehidupan demokrasi dunia. Berdasarkan hasil penelitian bahwa setiap guru IPS pada SMP Negeri di Kecamatan Sape berkewajiban menyusun RPP secara lengkap dan sistematis dengan mengintegrasikan nilai-nilai karakter bangsa dalam setiap komponen didalamnya agar peserta didik dapat memiliki kecakapan sosial yang mumpuni dalam lingkungan kemasyarakatan. RPP disusun untuk setiap KD yang dapat dilaksanakan dalam satu kali pertemuan atau lebih. Guru IPS merancang penggalan RPP untuk setiap pertemuan yang disesuaikan dengan penjadwalan di sekolah.

RPP dan Silabus untuk pembelajaran IPS pada Kurikulum 2013 di SMPN Kecamatan Sape, Bima di susun berdasarkan Peraturan Menteri Pendidikan dan Kebudayaan Nomor 22 Tahun 2016 memuat perencanaan pembelajaran yang memuat KI-1, KI-2, KI-3, KI-4, KD, materi pembelajaran, kegiatan pembelajaran, penilaian, alokasi waktu, dan sumber belajar yang memuat perencanaan penumbuhan budi pekerti secara memadai. Hasil penelitian ini sejalan dengan hasil kajian Ghufron (2010) terkait integrasi nilai-nilai karakter bangsa pada tahap perencanaan pembelajaran dengan terlebih dahulu mengkaji rumusan kegiatan yang akan dikuasai oleh peserta didik.

\section{KESIMPULAN}

Pengintegrasian nilai-nilai karakter dalam perencanaan pembelajaran IPS sudah cukup baik dimana dalam menyusun perangkat pembelajaran, guru sudah memodifikasi setiap komponen RPP yang dapat mengembangkan nilai-nilai karakter bangsa pada peserta didik sebagai acuan dalam pelaksanaan proses dan evaluasi pembelajaran pada tahap selanjutnya.

Integrasi karakter bangsa berbasis pendekatan saintifik dalam perencanaan pembelajaran IPS SMPN di Kecamatan Sape, Bima sudah cukup representatif dimana dalam menyusun perangkat pembelajaran, guru sudah memodifikasi setiap komponen yakni dengan mengembangkan perangkat pembelajaran berupa Silabus, Rencana Pelaksanaan Pembelajaran (RPP), dan bahan ajar yang dapat mengembangkan nilai-nilai karakter bangsa pada peserta didik sebagai acuan dalam pelaksanaan proses dan evaluasi pembelajaran pada tahap selanjutnya.

\section{SARAN}

Pihak SMPN di Kecamatan Sape perlu memberikan pelatihan terkait pendidikan karakter yang terintegrasi dalam perencanaan pembelajaran untuk meningkatkan kemampuan guru dalam mengimplementasikan pendidikan karakter berdasarkan Kurikulum 2013 dengan cara mendatangkan pakar yang mumpuni. Bagi guru IPS perlu lebih kreatif dalam mengembangkan perangkat pembelajaran yang didalamnya memuat nilai-nilai karakter dengan cara mendiskusikannya bersama tim guru dalam forum MGMP. 


\section{UCAPAN TERIMA KASIH}

Ucapan terima kasih kepada pihak KEMENRISTEKDIKTI sebagai sumber pendanaan penelitian melalui Program Hibah Penelitian Kategori Kompetitif Nasional 2019. Ucapan terima kasih juga pada seluruh responden di SMPN 1 dan SMPN 5 Sape, Kabupaten Bima, NTB atas kontributif besar atas penelitian ini serta kepada para Reviewer Nasional atas segala masukan dan kritikan yang berharga dalam penyempurnaan penelitian ini.

\section{DAFTAR PUSTAKA}

Afandi, R. (2011). Integrasi Pendidikan Karakter dalam Pembelajaran IPS di Sekolah Dasar. Jurnal Pedagogia-Universitas Muhamadiyah Sidoarjo, 1(1), 85-98.

Barth, L. J. (1990). Methods of instruction in social studies education. Lanham: University Press of America.

Cahyono, H. (2015). Pola Pengembangan Pendidikan Karakter Siswa. Jurnal Dimensi Pendidikan dan Pembelajaran, 3(2), 12-18.

Ellis, \& Arthur, K. (1997). Teaching and learning elementary social studies. United States: A Viacom Company.

Gay, L.R., Mills G., \& Airasian P. (2012). Educational Research: Competencies for Analysis and Applications, 10th ed. Boston: Pearson.

Ghufron, A. (2010). Integrasi Nilai-Nilai Karakter Bangsa pada Kegiatan Pembelajaran. Jurnal Cakrawala Pendidikan, XXIX, Edisi Dies Natalis UNY, 18-19.

Hanang AR Rasyid. (2016). Implementasi Pendidikan Karakter dalam Pembelajaran IPS di Madrasah Aliyah. Jurnal Ilmu-Ilmu Sosial-Universitas Negeri Yogyakarta, 15 (1), 3-4.

Kadek, I., \& Wirawa, W. (2014). Pelaksanaan Pendidikan Karakter Melalui Pembelajaran Sejarah. E-Jurnal Program Pascasarjana Universitas Pendidikan Ganesha, Program Studi Administrasi Pendidikan, 5. http://media.neliti.com>media

Kemendikbud. (2016). Panduan Pembelajaran Untuk Sekolah Menengah Pertama. Jakarta. Kemendikbud. 2015. Pusat Kurikulum dan Perbukuan.

Lickona, T. (1992). Educating for character, how our schools can teach respect, respect and responsibility. New York: Bantam Books.

Mardzuki. (2012) Pengintegrasian Pendidikan Karakter Dalam Pembelajaran di Sekolah. Jurnal Pendidikan Karakter, 2(1), 11-12.

Massialas, G., B. \& Allen, F., R. (1996). Critical issues in teaching social studies K-12. United States: Wadsworth Publishing Company.

Miles, M., B. \& Huberman, A., M. (1994). Analisis Data Kualitatif. Jakarta: Penerbit UI Press

Nadlir, M. (2016). Perencanaan Pembelajaran Berbasis Karakter. Jurnal Pendidikan Agama Islam, 1(2), 338-352.

Ningsih, S., W., S. (2017). Implementasi Pendidikan Karakter pada Mata Pelajaran IPS. Prosiding Seminar Nasional, (pp. 128-132). Medan, Indonesia: Universitas Negeri Medan.

Permendikbud. (2014) No 103, Pembelajaran pada Pendidikan Dasar dan Menengah. Permendikbud. (2016) No 22, Standar Proses pada Pendidikan Dasar dan Menengah. 
Puspitarini, A. K., Dantes, N., \& Tegeh, I., M. (2015). Pengaruh Pendekatan Saintifik dalam Pembelajaran IPS Terhadap Sikap Sosial dengan Kovariabel Intensitas Hubungan Dalam Pola Asuh Keluarga pada Siswa Kelas IV SD Perkotaan. EJournal PGSD Universitas Ganesha Jurusan PGSD, 3 (1). https:/ / ejournal.undiksha.ac.id

Subadi, N., C. \& Fathoni, A. (2018). Pengelolaan Pendidikan Karakter Kemandirian Belajar Pada Pembelajaran IPS di SMPN 1 Tawangsari. Tesis. Universitas Muhamadiyah Surakarta.

Sudrajat, A., \& Wibowo, A. (2013). Pembentukan Karakter Terpuji di Sekolah Dasar Muhamadiyah Condong Catur. Jurnal Pendidikan Karakter, 2(2), 20-21

Sujarwo. (2017). Penanaman Nilai-Nilai dalam Pendekatan Saintifik Pada Pembelajaran Ilmu Pengetahuan Sosial. Jurnal Edukasi IPS, 1(1), 11-20.

Wahyuningsih, S. \& Mustadi, A. (2015). Pengembangan RPP Tematik-Integratif untuk Meningkatkan Karakter Kerja Keras di Kelas 1 SDN Sokoraja Tengah. Jurnal Prima Edukasia, 3 (2), 190-201.

Wardana, A. L., \& Husen, C. (2017). Implementasi Pendekatan Saintifik Untuk Meningkatkan Prestasi Belajar Siswa pada Mata Pelajaran IPS. Jurnal Pendidikan Dasar Nusantara, 3 (1). http:/ / ojs.unpkediri.ac.id

Zuchdi, D., Kun, Z., \& Siasah, M. (2010). Pengembangan Model Pendidikan Karakter Terintegrasi dalam Pembelajaran Bidang Studi di Sekolah Dasar. Jurnal Cakrawala Pendidikan, Mei Th. XXIX, Edisi Khusus Dies Natalis UNY, 13-24. 